\title{
Drying Effects on Chemical Composition and Antioxidant Activity of Lippia thymoides Essential Oil, a Natural Source of Thymol
}

\author{
Lidiane Diniz do Nascimento ${ }^{1,2, *} \mathbb{1}$, Sebastião Gomes Silva ${ }^{3}{ }^{\circ}$, Márcia Moraes Cascaes 4 , \\ Kauê Santana da Costa ${ }^{5, *}$, , Pablo Luis Baia Figueiredo ${ }^{6}{ }^{\circ}$, Cristiane Maria Leal Costa ${ }^{7}$, \\ Eloisa Helena de Aguiar Andrade ${ }^{2,4}$ and Lênio José Guerreiro de Faria ${ }^{1,7}$
}

check for

updates

Citation: Nascimento, L.D.d.; Silva, S.G.; Cascaes, M.M.; Costa, K.S.d.;

Figueiredo, P.L.B.; Costa, C.M.L.; Andrade, E.H.d.A.; de Faria, L.J.G. Drying Effects on Chemical

Composition and Antioxidant Activity of Lippia thymoides Essential Oil, a Natural Source of Thymol. Molecules 2021, 26, 2621. https:// doi.org/10.3390/molecules26092621

Academic Editor: Laura De Martino

Received: 24 February 2021

Accepted: 10 March 2021

Published: 30 April 2021

Publisher's Note: MDPI stays neutral with regard to jurisdictional claims in published maps and institutional affiliations.

Copyright: (c) 2021 by the authors. Licensee MDPI, Basel, Switzerland. This article is an open access article distributed under the terms and conditions of the Creative Commons Attribution (CC BY) license (https:/ / creativecommons.org/licenses/by/ $4.0 /)$.
1 Programa de Pós-Graduação em Engenharia de Recursos Naturais da Amazônia, Universidade Federal do Pará, Belém 66075-110, Pará, Brazil; leniojgfaria@gmail.com

2 Coordenação de Botânica, Museu Paraense Emílio Goeldi, Belém 66077-830, Pará, Brazil; eloisa@museu-goeldi.br

3 Instituto de Ciências Exatas e Naturais, Universidade Federal do Pará, Belém 66075-110, Pará, Brazil; profsebastiaogs@gmail.com

4 Programa de Pós-Graduação em Química, Universidade Federal do Pará, Belém 66075-110, Pará, Brazil; cascaesmm@gmail.com

5 Faculdade de Biotecnologia, Instituto de Biodiversidade, Universidade Federal do Oeste do Pará, Santarém 68035-110, Pará, Brazil

6 Departamento de Ciências Naturais, Universidade do Estado do Pará, Belém 66050-540, Pará, Brazil; pablo.figueiredo@uepa.br

7 Programa de Pós-Graduação em Engenharia Química, Universidade Federal do Pará, Belém 66075-110, Pará, Brazil; cristianemlcosta@gmail.com

* Correspondence: lidianenascimento@museu-goeldi.br (L.D.d.N.); kaue.costa@ufopa.edu.br (K.S.d.C.); Tel.: +55-91-3217-6086 (L.D.d.N.); +55-93-2101-6771 (K.S.d.C.)

Abstract: Leaves of Lippia thymoides (Verbenaceae) were dried in an oven at 40,50 and $60{ }^{\circ} \mathrm{C}$ and the kinetic of drying and the influence of the drying process on the chemical composition, yield, and DPPH radical scavenging activity of the obtained essential oils were evaluated. The composition of the essential oils was determined with gas chromatography-mass spectrometry and gas chromatography-flame ionization detection analyses. The influence of drying on the chemical composition of the essential oils of L. thymoides was evaluated by multivariate analysis, and their antioxidant activity was investigated via the 2,2-diphenyl-1-picrylhydrazyl (DPPH) assay. The Midilli model was the most appropriate to describe the behavior of drying kinetic data of L. thymoides leaves. Thymol was the major compound for all analyzed conditions; the maximum content was obtained from fresh leaves $(62.78 \pm 0.63 \%)$. The essential oils showed DPPH radical scavenging activity with an average of $73.10 \pm 12.08 \%$, and the fresh leaves showed higher inhibition (89.97 $\pm 0.31 \%$ ). This is the first study to evaluate the influence of drying on the chemical composition and antioxidant activity of L. thymoides essential oils rich in thymol.

Keywords: drying kinetics; thymol; yield; multivariate analysis; DPPH

\section{Introduction}

Essential oils and their constituents have been described as antioxidants [1-5], food preservatives [6-8], and mosquito repellents [9-11]. Essential oils containing thymol as a major component have been used in the industry as flavorings and food preservatives, and even in aromatherapy $[4,12,13]$. This compound has been registered by the European Commission for use as flavoring in foodstuffs; it is also used as a food additive in the USA and China [12,14]. Furthermore, isolated thymol as well as essential oils with high levels of thymol demonstrated a protective action in the treatment of soybean seeds [15]; they also exhibit antifungal [16-18], antibacterial [19,20], antiviral [21], and antioxidant 
activities [13]. A previous study investigated the antioxidant activity of some pure essential oil components using lipid model systems and concluded that phenolic compounds were efficient antioxidants and that thymol was one of the most active components in the class of oxygenated monoterpenes [22]. Furthermore, thymol has been indicated as an alternative to synthetic antioxidants in the food matrix [14].

Lippia thymoides Mart. \& Schauer (syn Lippia micromera var. tonsilis Moldenke) belongs to Verbenaceae [23-25] and has been extensively investigated for the biological activities associated with its oil or extract. Silva et al. (2015) [26] validated the traditional use of L. thymoides for the treatment of wounds and fever. The dichloromethane fraction showed antimicrobial activities against the species Bacillus cereus, Candida parapsilosis, and Staphylococcus aureus [26]. In addition, Pinto et al. (2013) [27] evaluated the methanolic extracts of leaves, branches, and flowers of L. thymoides, which exhibited antimicrobial activity against Staphylococcus aureus; these results corroborated its traditional use in the treatment of infectious diseases [27]. Despite the importance of this species in traditional medicine, few studies have reported the chemical composition of L. thymoides essential oil [28-31].

The drying process prolongs the shelf life of products, inhibiting chemical and enzymatic reactions. However, drying can cause changes in the yield of essential oils, polyphenols, pigments, and vitamin contents as well as appearance, taste, and color [32]. Different drying techniques have been applied to various aromatic plants to evaluate the effect of drying on the color, composition, and yield of the essential oils as well as to determine the best method for drying a specific plant [33-37].

The drying process can directly affect the composition and yield of essential oils, but this varies according to each species and drying method applied. In the present study, we evaluated for the first time the effect of the air temperature on the thin-layer drying kinetics and the influence of different drying conditions on the chemical composition, yield, and antioxidant activity of the essential oil of Lippia thymoides Mart. \& Schauer (Verbanaceae) rich in thymol.

\section{Results and Discussion}

\subsection{Drying Kinetics}

The initial moisture content of $L$. thymoides fresh leaves was $68.15 \pm 0.01 \%$ on a wet basis. At the end of the drying process, the moisture content was $31.28 \pm 1.51 \%$ for the $40{ }^{\circ} \mathrm{C}$ conditions, $12.34 \pm 0.09 \%$ at $50{ }^{\circ} \mathrm{C}$, and $9.29 \pm 0.07 \%$ at $60{ }^{\circ} \mathrm{C}$. During the drying of $L$. thymoides leaves, the moisture ratio decreased exponentially, and an increase in the air temperature led to higher water removal from plant matrices (Figure 1). To explain a similar behavior, Perea-Flores et al. (2012) [38] reported that during the falling period, the surface of the material was no longer saturated with water, and that the phenomenon of internal diffusion controlled the drying rate [38]. The kinetic curves in Figure 1 presented a typical pattern of drying plots [39-41]. In the present study, the moisture ratio reached stable values in the range of 0.03 after $350 \mathrm{~min}\left(40^{\circ} \mathrm{C}\right), 210 \mathrm{~min}\left(50^{\circ} \mathrm{C}\right)$, and $160 \mathrm{~min}\left(60{ }^{\circ} \mathrm{C}\right)$, as presented in Figure 1. In this condition, we obtained a moisture content of $6.54 \%$ on a wet basis. The pattern of the kinetic drying curves described in Figure 1 is in accordance with the results previously described for Ocimum basilicum [42,43] and Warionia saharae [44].

Kucuk et al. (2014) [45] reported that different models have been applied to predict drying conditions of several products [45]. The Midilli model presented the best fit of the experimental drying data at different temperatures (Table 1, Figure 1), and presented $S E E<0.02 \%$ and $M R E<1.18 \%$. The $R^{2}$ values were $99.91 \%\left(40{ }^{\circ} \mathrm{C}\right), 99.95 \%\left(50{ }^{\circ} \mathrm{C}\right)$, and $99.87 \%\left(60^{\circ} \mathrm{C}\right)$. The Midilli model is indicated to describe the thin layer drying process [45] and it was appropriated to describe the drying kinetic of L. thymoides. Midilli was also suitable for describing the drying curves of leaves of Piper umbellatum [46], Ocimum basilicum [43], and Vernonia amygdalina [47]. 
Table 1. Parameters of the models applied to the experimental data analyses of the drying kinetic curves of Lippia thymoides leaves.

\begin{tabular}{|c|c|c|c|c|c|c|c|c|}
\hline Models & $\begin{array}{c}\text { Temperature } \\
\left({ }^{\circ} \mathrm{C}\right)\end{array}$ & \multicolumn{4}{|c|}{ Parameters } & $\begin{array}{l}R^{2} \\
(\%)\end{array}$ & $\begin{array}{c}\text { MRE } \\
(\%)\end{array}$ & $\begin{array}{l}S E E \\
(\%)\end{array}$ \\
\hline \multicolumn{9}{|c|}{$k$} \\
\hline \multirow{4}{*}{ Lewis } & 40 & \multicolumn{4}{|c|}{0.0076} & 99.504 & 17.0104 & 0.0333 \\
\hline & 50 & \multicolumn{4}{|c|}{0.0115} & 99.274 & 27.8596 & 0.0423 \\
\hline & 60 & \multicolumn{4}{|c|}{0.0179} & 99.492 & 0.8904 & 0.0329 \\
\hline & & \multicolumn{2}{|r|}{$a$} & \multicolumn{2}{|c|}{$k$} & & & \\
\hline \multirow{3}{*}{$\begin{array}{l}\text { Henderson \& } \\
\text { Pabis }\end{array}$} & 40 & \multicolumn{2}{|r|}{1.039} & \multicolumn{2}{|c|}{0.0079} & 99.627 & 14.0965 & 0.0298 \\
\hline & 50 & \multicolumn{2}{|r|}{1.0611} & \multicolumn{2}{|c|}{0.0122} & 99.485 & 19.4258 & 0.0367 \\
\hline & 60 & \multicolumn{2}{|r|}{1.0351} & \multicolumn{2}{|c|}{0.0185} & 99.552 & 3.1528 & 0.0318 \\
\hline & & \multicolumn{2}{|r|}{$n$} & \multicolumn{2}{|c|}{$k$} & & & \\
\hline \multirow{4}{*}{ Page } & 40 & \multicolumn{2}{|r|}{1.1787} & \multicolumn{2}{|c|}{0.0032} & 99.833 & 2.5868 & 0.0159 \\
\hline & 50 & \multicolumn{2}{|r|}{1.2794} & \multicolumn{2}{|c|}{0.0033} & 99.923 & 12.0830 & 0.0141 \\
\hline & 60 & \multicolumn{2}{|r|}{1.2076} & \multicolumn{2}{|c|}{0.0077} & 99.780 & 25.8821 & 0.0214 \\
\hline & & \multicolumn{2}{|l|}{$a$} & \multicolumn{2}{|c|}{$k$} & & & \\
\hline \multirow{4}{*}{$\begin{array}{l}\text { Diffusion } \\
\text { approach }\end{array}$} & 40 & -0.6480 & 0.5837 & \multicolumn{2}{|c|}{0.0173} & 99.890 & 5.0964 & 0.0161 \\
\hline & 50 & -2.0200 & 0.7479 & & & 99.926 & 8.3433 & 0.0143 \\
\hline & 60 & -2.9001 & 0.8332 & & & 99.815 & 24.5185 & 0.0211 \\
\hline & & $a$ & $b$ & $n$ & $k$ & & & \\
\hline & 40 & 0.9880 & $-5.5 \times 10^{-5}$ & 1.1638 & 0.0032 & 99.912 & 1.1798 & 0.0157 \\
\hline Midilli et al. & 50 & 0.9777 & $-3.8 \times 10^{-5}$ & 1.3538 & 0.0023 & 99.951 & 0.9000 & 0.0120 \\
\hline & 60 & 0.9721 & $-6.6 \times 10^{-5}$ & 1.2969 & 0.0053 & 99.877 & 0.9241 & 0.0177 \\
\hline & & & $a$ & & & & & \\
\hline & 40 & & -0.0058 & & & 99.920 & 1.1627 & 0.0141 \\
\hline Wang \& Singh & 50 & & -0.0077 & 1.4 & & 99.017 & 25.2498 & 0.0506 \\
\hline & 60 & & -0.0092 & 1.9 & & 92.270 & 62.1788 & 0.1297 \\
\hline
\end{tabular}

Note: $k$ is the drying constant $\left(\mathrm{min}^{-1}\right) ; a, b$, and $n$ are the model coefficients; MRE: mean relative error; SEE: standard error of estimate; and $R^{2}$ : coefficient of determination.

According to Table 1, for the Lewis, Diffusion approach, and Henderson \& Pabis models, the " $k$ " values increased as the drying temperature increased. However, for the Page and Midilli models, the temperature variation $\left(40,50\right.$ and $\left.60{ }^{\circ} \mathrm{C}\right)$ did not cause a defined trend in the values of " $k$ ". The parameter " $k$ " is defined as the constant of drying $\left(\mathrm{min}^{-1}\right)$ and according to Dorneles et al. (2019) [46], it is related to the effective diffusivity during the falling period of kinetic drying, in which liquid diffusion controls the process [46]. 


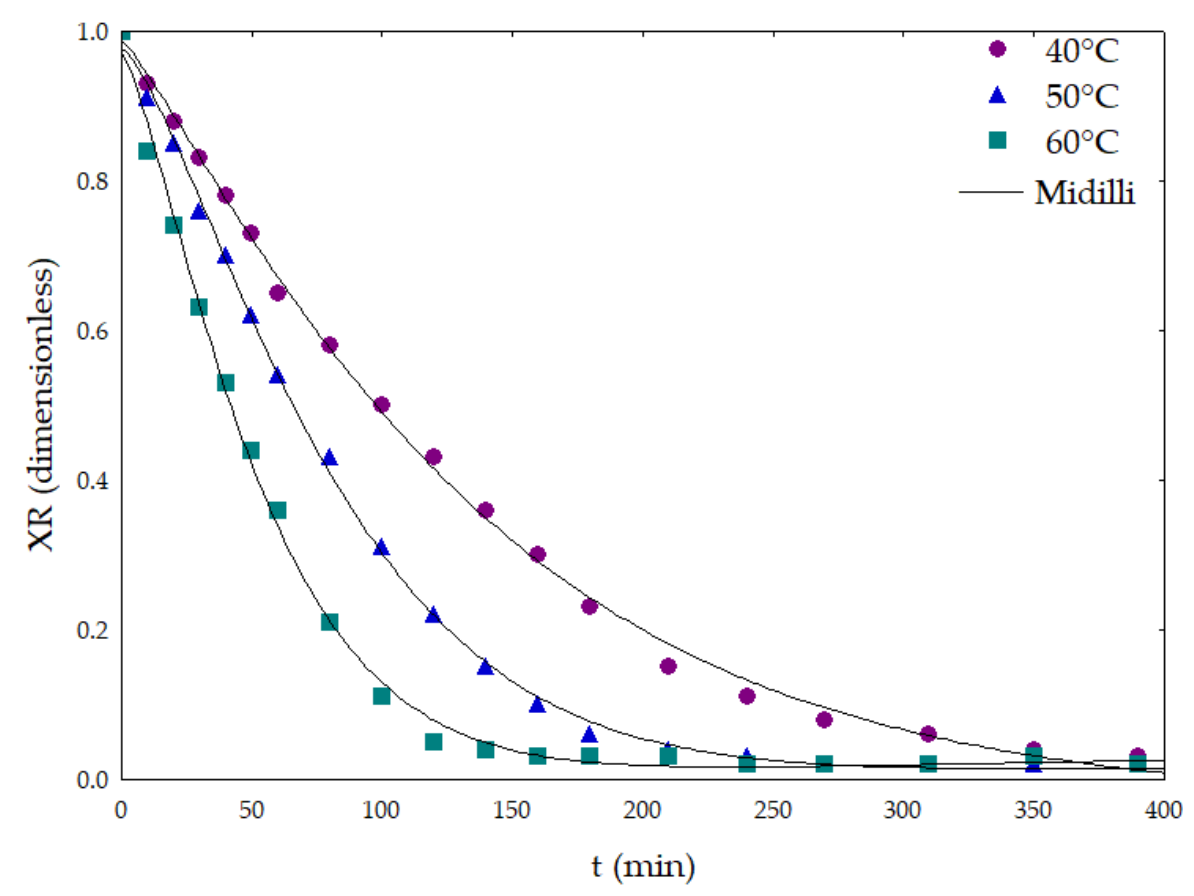

Figure 1. Values of moisture ratio versus time in thin-layer drying of Lippia thymoides leaves, adjusted using the Midilli model.

\subsection{Drying Effects on Essential Oil Yield}

The drying conditions had a significant effect on the yield of the essential oils $(p<0.05)$ (Table 2). The yield obtained from fresh leaves of L. thymoides was similar to the yield obtained by drying for $390 \mathrm{~min}$ at $60{ }^{\circ} \mathrm{C}(0.50 \%$ on average $)$. The highest yields were obtained for dried leaves at $40{ }^{\circ} \mathrm{C}$ and $50{ }^{\circ} \mathrm{C}(0.74 \%$ on average). Therefore, according to the experimental conditions here described, to achieve better yields, it is necessary to reduce the moisture content of L. thymoides leaves, but the samples should be dried at temperatures in the range of 40 to $50^{\circ} \mathrm{C}$. At higher temperatures such as $60^{\circ} \mathrm{C}$, there is a greater loss in the components by volatilization, resulting in lower yields during extraction.

Considering the storage structures found in different organs and the volatile constituents of the aromatic plants, the selection of the appropriate drying methods is important because drying can affect the yield and the chemical composition of the essential oil $[35,48]$. We did not find previous studies evaluating the effect of different drying conditions on the yield of essential oil of L. thymoides, however, Ebadi et al. (2015) [49] investigated the drying of Lippia citriodora leaves using different methodologies including oven-drying $\left(40,50\right.$, and $\left.60^{\circ} \mathrm{C}\right)$, and they found that the increase in temperature generated damage to glandular trichomes, which may have favored the loss of volatiles and the reduction in the yield [49]. Mashkani et al. (2018) [50] subjected the leaves of Thymus daenensis to different drying methods (sun and shade, oven, microwave, and vacuum drying) and observed that, in general, there was a reduction in the yield of essential oils at increased temperatures [50]. Alves et al. (2015) [51] investigated the influence of Ocimum basilicum leaf-drying on the yield and composition of the essential oil and observed that the oil yield decreased linearly over eight days at $40{ }^{\circ} \mathrm{C}(6.0 \%$ to $3.9 \%)$ [51]. Therefore, an increase in the temperature contributes to high evaporation rates, which can damage the cells that store the essential oil, intensifying the release of volatile compounds and resulting in lower yields after extraction. 
Table 2. Yield, chemical constituents and their percentage variation in the essential oils of Lippia thymoides leaves after the drying process at 40,50 , and $60^{\circ} \mathrm{C}$.

\begin{tabular}{|c|c|c|c|c|c|c|}
\hline & & & Fresh & $40^{\circ} \mathrm{C}$ & $50{ }^{\circ} \mathrm{C}$ & $60{ }^{\circ} \mathrm{C}$ \\
\hline & & Yield * (\%) & $0.53^{a} \pm 0.01$ & $0.72^{b} \pm 0.01$ & $0.76^{b} \pm 0.00$ & $0.46^{a} \pm 0.09$ \\
\hline $\mathbf{R I}_{\mathbf{L}}$ & $\mathbf{R I}_{\mathbf{C}}$ & Compound & Area $\%$ & Area \% & Area \% & Area $\%$ \\
\hline 924 & 927 & $\alpha$-thujene & - & $0.78 \pm 0.04$ & $0.27 \pm 0.38$ & $0.62 \pm 0.23$ \\
\hline 988 & 985 & Myrcene & $0.52 \pm 0.62$ & $2.46 \pm 1.39$ & $2.10 \pm 1.15$ & $2.16 \pm 0.48$ \\
\hline 1002 & 1005 & $\alpha$-phellandrene & - & $0.26 \pm 0.00$ & $0.11 \pm 0.15$ & $0.23 \pm 0.02$ \\
\hline 1014 & 1012 & $\alpha$-terpinene & $0.37 \pm 0.45$ & $1.70 \pm 0.97$ & $1.39 \pm 0.76$ & $1.40 \pm 0.13$ \\
\hline 1020 & 1019 & $p$-cymene & $2.97 \pm 2.79$ & $8.75 \pm 3.08$ & $8.36 \pm 3.54$ & $8.97 \pm 0.64$ \\
\hline 1022 & 1025 & o-cymene & $0.04 \pm 0.05$ & $0.35 \pm 0.49$ & $2.28 \pm 0.57$ & - \\
\hline 1044 & 1042 & $E$ - $\beta$-ocimene & - & $0.04 \pm 0.05$ & $0.08 \pm 0.11$ & $0.12 \pm 0.01$ \\
\hline 1054 & 1056 & $\gamma$-terpinene & $2.75 \pm 3.55$ & $9.54 \pm 0.59$ & $12.36 \pm 4.64$ & $8.19 \pm 0.28$ \\
\hline 1065 & 1064 & cis-sabinene hydrate & $0.05 \pm 0.06$ & $0.02 \pm 0.03$ & - & $0.18 \pm 0.00$ \\
\hline 1086 & 1088 & Terpinolene & - & $0.08 \pm 0.12$ & $0.20 \pm 0.04$ & $0.17 \pm 0.01$ \\
\hline 1095 & 1099 & Linalool & $0.03 \pm 0.04$ & $0.13 \pm 0.18$ & $0.27 \pm 0.07$ & $0.19 \pm 0.00$ \\
\hline 1098 & 1104 & trans-sabynene hydrate & - & $0.05 \pm 0.07$ & $0.04 \pm 0.05$ & - \\
\hline 1141 & 1146 & Camphor & - & $0.02 \pm 0.00$ & $0.03 \pm 0.00$ & - \\
\hline 1167 & 1175 & Umbellulone & $0.88 \pm 0.04$ & $1.48 \pm 2.02$ & $0.06 \pm 0.02$ & $0.28 \pm 0.36$ \\
\hline 1174 & 1180 & Terpinen-4-ol & $0.73 \pm 0.13$ & $1.05 \pm 1.01$ & $1.44 \pm 0.10$ & - \\
\hline 1232 & 1237 & Thymol methyl ether & $1.28 \pm 0.30$ & $2.69 \pm 1.54$ & $1.47 \pm 0.09$ & $1.28 \pm 0.03$ \\
\hline 1289 & 1297 & Thymol & $62.78 \pm 0.63$ & $49.21 \pm 11.46$ & $53.03 \pm 11.76$ & $59.29 \pm 2.89$ \\
\hline 1349 & 1356 & Thymyl acetate & $7.22 \pm 2.30$ & $6.46 \pm 0.72$ & $5.25 \pm 0.45$ & $4.92 \pm 0.10$ \\
\hline 1374 & 1379 & $\alpha$-copaene & - & $0.02 \pm 0.02$ & $0.04 \pm 0.01$ & $0.07 \pm 0.00$ \\
\hline 1387 & 1388 & $\beta$-bourbonene & - & $0.02 \pm 0.00$ & $0.02 \pm 0.02$ & $0.03 \pm 0.00$ \\
\hline 1417 & 1425 & E-caryophyllene & $8.84 \pm 1.10$ & $8.08 \pm 0.26$ & $7.46 \pm 0.56$ & $5.21 \pm 0.44$ \\
\hline 1432 & 1439 & $\alpha$-trans-bergamotene & $0.23 \pm 0.04$ & $0.39 \pm 0.34$ & $0.13 \pm 0.01$ & - \\
\hline 1452 & 1458 & $\alpha$-humulene & $1.49 \pm 0.22$ & $1.75 \pm 1.00$ & $0.89 \pm 0.09$ & $0.79 \pm 0.07$ \\
\hline 1484 & 1486 & Germacrene D & $0.59 \pm 0.13$ & $0.79 \pm 0.26$ & $0.37 \pm 0.07$ & $0.40 \pm 0.02$ \\
\hline 1495 & 1499 & $\gamma$-amorphene & - & $0.05 \pm 0.06$ & $0.09 \pm 0.00$ & $0.24 \pm 0.00$ \\
\hline 1500 & 1504 & $\alpha$-muurolene & - & $0.20 \pm 0.17$ & $0.07 \pm 0.01$ & $0.14 \pm 0.01$ \\
\hline 1513 & 1519 & $\gamma$-cadinene & $0.42 \pm 0.14$ & $0.36 \pm 0.28$ & $0.15 \pm 0.02$ & $0.22 \pm 0.01$ \\
\hline 1522 & 1528 & $\delta$-cadinene & $0.78 \pm 0.24$ & $0.77 \pm 0.63$ & $0.30 \pm 0.03$ & $0.41 \pm 0.04$ \\
\hline 1582 & 1589 & Caryophillene oxide & $1.09 \pm 0.40$ & $1.01 \pm 0.86$ & $0.30 \pm 0.07$ & $1.06 \pm 0.05$ \\
\hline 1608 & 1615 & Humulene epoxide II & - & $0.02 \pm 0.03$ & $0.01 \pm 0.01$ & $0.14 \pm 0.01$ \\
\hline 1640 & 1646 & epi- $\alpha$-murrolol & - & $0.02 \pm 0.02$ & - & $0.07 \pm 0.02$ \\
\hline \multirow[t]{6}{*}{1652} & 1659 & $\alpha$-cadinol & - & $0.02 \pm 0.03$ & - & $0.07 \pm 0.01$ \\
\hline & & Monoterpene hydrocarbons & $6.70 \pm 7.49$ & $23.95 \pm 4.35$ & $27.14 \pm 11.35$ & $21.85 \pm 1.80$ \\
\hline & & Oxygenated monoterpenes & $72.95 \pm 2.89$ & $61.1 \pm 7.50$ & $61.56 \pm 11.08$ & $66.14 \pm 1.38$ \\
\hline & & Sesquiterpene hydrocarbons & $12.35 \pm 1.91$ & $12.41 \pm 2.32$ & $9.49 \pm 0.85$ & $7.5 \pm 0.59$ \\
\hline & & Oxygenated sesquiterpene & $1.1 \pm 0.42$ & $1.07 \pm 0.78$ & $0.31 \pm 0.06$ & $1.33 \pm 0.09$ \\
\hline & & Total $* *$ & $90.07 \pm 3.11$ & $98.53 \pm 0.05$ & $98.49 \pm 1.17$ & $96.79 \pm 0.26$ \\
\hline
\end{tabular}

Notes: * Columns with the same letter did not differ by the Tukey test at $5 \%$ probability; $\mathrm{RI}_{(\mathrm{L})}$ : Retention index from literature $[52,53]$; $\mathrm{RI}_{(\mathrm{c})}$ : Retention index calculated using an $n$-alkane standard solutions (C8-C40) in column DB5-MS; ${ }^{* *}$ Relative percentage areas calculated based on the peak areas.

\subsection{Drying Effects on Chemical Composition}

Thirty-two volatile constituents were identified, comprising a range of $90.07 \pm 3.11 \%$ to $98.53 \pm 0.05 \%$ of the total composition of the analyzed essential oils (Table 2). Thymol was the major compound obtained from both fresh and dried leaves. The highest content was observed in fresh leaves $(62.78 \pm 0.63 \%)$, while the levels in the extracted essential oils after drying at 40 , 50 and $60{ }^{\circ} \mathrm{C}$ were $49.21 \pm 11.46 \%, 53.03 \pm 11.76 \%$, and $59.29 \pm 2.89 \%$, respectively.

Besides thymol, the main components identified in the L. thymoides essential oil were $p$-cymene $(2.97 \pm 2.79 \%-8.97 \pm 0.64 \%), \gamma$-terpinene $(2.75 \pm 3.55 \%-12.36 \pm 4.64 \%)$, thymyl acetate $(4.92 \pm 0.10 \%-7.22 \pm 2.30 \%)$, and $E$-caryophyllene $(5.21 \pm 0.44 \%-8.84 \pm 1.10 \%)$. The oxygenated monoterpenes were the predominant chemical class, reaching the highest level in fresh leaves $(72.95 \pm 2.89 \%)$. These results were in agreement with previously 
published data on the composition of L. thymoides essential oils [30,31], but differed from the composition described by Silva et al. (2016) [29], who found an essential oil with high levels of $\beta$-caryophyllene (17.22-26.27\%), borneol (4.45-7.36\%), camphor (3.22-8.61\%), camphene (2.64-5.66\%), and germacrene D (4.72-6.18\%) [29].

Here, we utilized the multivariate analysis to investigate possible similarities between the chemical classes of the constituents identified in the essential oils of the fresh and dried leaves of L. thymoides (Table 2). From the PCA data (Figure 2A), we deducted a fitting of $85.57 \%(\mathrm{PC} 1+\mathrm{PC} 2)$ of the chemical variation in the samples. The principal components (PC1 and PC2) divided the chemical composition of the fresh and dried leaves into two groups (Figure 2A).
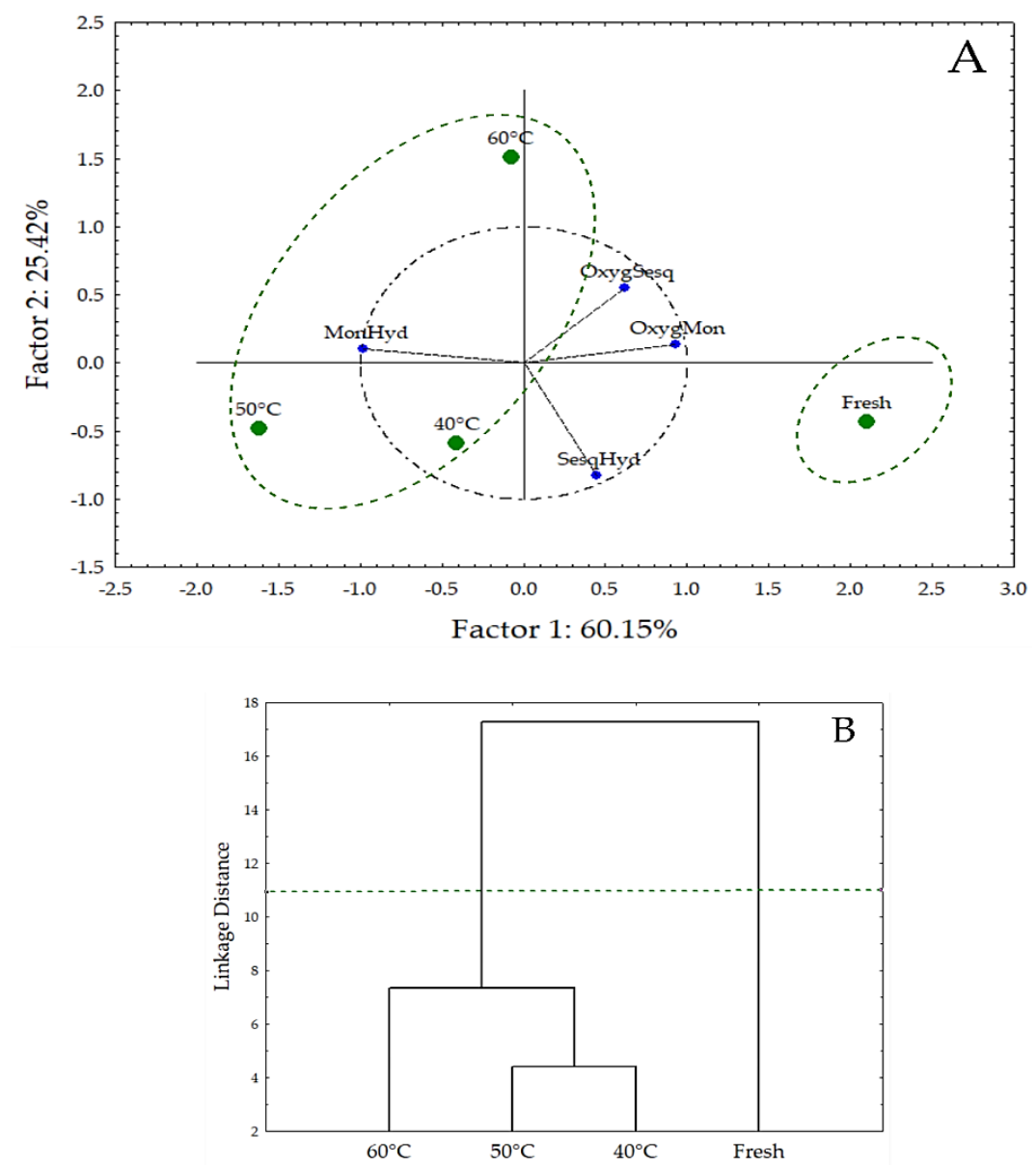

Figure 2. Multivariate analysis using data from the chemical composition of essential oils obtained from fresh and dried Lippia thymoides leaves. (A) Principal component analysis (PCA); MonHyd: Monoterpene hydrocarbons; OxygSesq: Oxygenated sesquiterpene; OxygMon: Oxygenated monoterpenes; SesqHyd: Sesquiterpene hydrocarbons. (B) Hierarchical cluster analysis (HCA). The dashed green lines indicate the identified groupings.

These results confirmed that regardless of the applied drying temperature $(40,50$ and $60^{\circ} \mathrm{C}$ ), the essential oils extracted from the dried leaves had a similar chemical profile and formed Group 1. The percentages of monoterpene hydrocarbons increased in essential oils extracted from leaves after the drying process when compared to fresh leaves. However, for the class of oxygenated monoterpenes, a reduction in their contents was detected when compared to oil extracted from fresh leaves (control). This variation may have favored the formation of Group 2, composed only by the chemical constituents of the fresh leaves, which was confirmed by the analysis of the dendrogram in Figure 2B. 
Previously, a drying study described the effect of temperature and air velocity of drying on the composition of the Piper umbellatum leaves. They also reported a significant difference between the chemical profile of the fresh and dried leaves, but they found little difference between the samples dried at $40,50,60$ and $70{ }^{\circ} \mathrm{C}\left(0.4\right.$ and $\left.0.7 \mathrm{~m} . \mathrm{s}^{-1}\right)$ [46].

Other studies have also evaluated the effect of drying on monoterpene content and reported an effect similar to that described in the present study. Mashkani et al. (2018) [50] evaluated different drying methods for Thymus daenensis and observed that when compared with fresh plants, oven-drying at $35^{\circ} \mathrm{C}$ after a pre-drying operation resulted in a higher content in monoterpene hydrocarbons and reduced the oxygenated monoterpenes (especially the content of thymol and carvacrol) [50]. Shahhoseini et al. (2013) [54] subjected the aerial flowering parts of Lippia citriodora to different drying methods and observed that during oven-drying, the percentage of monoterpene hydrocarbons increased and those of oxygenated monoterpenes decreased with an increase in the drying temperature [54].

The thymol content decreased after the drying process when compared to the content presented in the fresh leaves. Similarly, Calín-Sánchez et al. (2013) [55] evaluated the effects of different methodologies and temperatures in the chemical composition of Thymus vulgaris essential oils, which presented high levels of thymol. They found $732 \mathrm{mg} \cdot 100 \mathrm{~g}^{-1}$ of thymol in the fresh leaves and after oven-drying, the levels changed to $571 \mathrm{mg} \cdot 100 \mathrm{~g}^{-1}$ $\left(40{ }^{\circ} \mathrm{C}\right), 479 \mathrm{mg} \cdot 100 \mathrm{~g}^{-1}\left(50^{\circ} \mathrm{C}\right)$, and $451 \mathrm{mg} \cdot 100 \mathrm{~g}^{-1}\left(60^{\circ} \mathrm{C}\right)$ [55]. In the study with the essential oil of Lippia origanoides, Queiroz et al. (2018) [56] also observed a reduction in thymol content after the drying process [56]. Therefore, the authors found that the drying process promoted a reduction in the levels of thymol, which corroborate with our results.

\subsection{Antioxidant Activity}

The DPPH radical scavenging activity of the essential oils of L. thymoides obtained from fresh and dried leaves $\left(40^{\circ} \mathrm{C}, 50^{\circ} \mathrm{C}\right.$, and $\left.60^{\circ} \mathrm{C}\right)$ are listed in Table 3 . The variation in drying temperature did not show a defined trend in the results of antioxidant activity, but the highest percentage of inhibition of the DPPH radical was observed for the essential oil sample from the fresh material $(89.97 \pm 0.31 \%)$, which presented the highest percentage of thymol (62.78\%, Table 2). In our study, we observed that the samples of the essential oils obtained after the drying process showed lower antioxidant activity, which may be associated with lower levels of thymol. A previous study investigated the antioxidant activity of some pure essential oil components using lipid model systems, and the authors concluded that the phenolic compounds were efficient antioxidants and they considered thymol as one of the most active components in the class of oxygenated monoterpenes [22]. It is interesting to note that thymol has been indicated as an alternative to synthetic antioxidants in the food matrix [14].

Table 3. Antioxidant activity of the essential oils of the fresh and dried leaves of Lippia thymoides.

\begin{tabular}{ccc}
\hline & \multicolumn{2}{c}{ Antioxidant Activity } \\
\hline Sample & $\begin{array}{c}\text { Trolox Equivalent } \\
\left(\mathbf{m g T E} \cdot \mathbf{m L}^{-\mathbf{1})}\right.\end{array}$ & $\begin{array}{c}\text { Inhibition } \\
\mathbf{( \% )}\end{array}$ \\
\hline Fresh & $231.26^{\mathrm{a}} \pm 0.79$ & $89.97^{\mathrm{a}} \pm 0.31$ \\
$40^{\circ} \mathrm{C}$ & $163.31^{\mathrm{b}} \pm 12.96$ & $63.53^{\mathrm{b}} \pm 5.04$ \\
$50^{\circ} \mathrm{C}$ & $189.26^{\mathrm{c}} \pm 5.38$ & $73.63^{\mathrm{c}} \pm 2.09$ \\
$60^{\circ} \mathrm{C}$ & $167.80^{\mathrm{b}} \pm 7.02$ & $65.28^{\mathrm{b}} \pm 2.74$
\end{tabular}

* Values are expressed as mean \pm standard deviation $(n=3)$. Values followed by the same letter did not differ by the Tukey test at $5 \%$ probability.

Although the chemical composition of the essential oils extracted after drying presented high similarity (Figure 2B), only the oils of L. thymoides extracted from dried leaves at $40^{\circ} \mathrm{C}$ and $60^{\circ} \mathrm{C}$ inhibited the DPPH radical in a statistically similar manner (Table 3). Natural products such as extracts and essential oils are formed by a complex mixture of organic compounds that act synergistically, increasing the biological activity or even antagonistically, thus reducing the verified activity, so identifying the compounds involved 
with a given biological response represents a methodological challenge [57-59]. Based on this, we conjecture that this variation in the results of DPPH inhibition percentage for the dried leaves could be involved with the synergist or antagonist effects (Table 3). Other studies identified synergist effects in the antioxidant [60] and antibacterial [61-63] activities of essential oils. For example, Ranjbaran et al. (2019) [13] reported that the high antioxidant activity of Trachyspermum ammia essential oil could be associated with the strong synergism between the monoterpenes ( $p$-cymene and $\gamma$-terpinene), the phenolic monoterpenes (thymol), and the oxygenated monoterpenes [13].

Essential oils with high thymol contents have been evaluated for their DPPH radical scavenging activities such as the essential oil from Trachyspermum ammia [13]. This essential oil showed robust antioxidant activity, which may be associated with its high content of thymol $(40.25 \%)$. Using the DPPH method, the $\mathrm{IC}_{50}$ were $54 \pm 3.2 \mu \mathrm{g} \cdot \mathrm{mL}^{-1}$ and $90 \pm 5.4 \mu \mathrm{g} \cdot \mathrm{mL}^{-1}$ for the essential oil and thymol, respectively [13]. The essential oil of oregano (Origanum vulgare) with thymol $(45 \%)$ and carvacrol $(37.4 \%)$ as the major compounds was subjected to DPPH radical scavenging tests and resulted in $\mathrm{IC}_{50}$ values between $0.76 \mu \mathrm{g} \cdot \mathrm{mL}^{-1}$ and $0.33 \mu \mathrm{g} \cdot \mathrm{mL}^{-1}$, indicating that this essential oil is an interesting natural source of antioxidant compounds with applications in the chemical, pharmaceutical, cosmetics, and food industries [64].

Few studies have reported the antioxidant profile of the essential oil of the species L. thymoides. Silva et al. (2016) [29] applied scavenging of the DPPH free radical and $\beta$ carotene bleaching tests to determine the antioxidant potential of the L. thymoides essential oil, rich in E-caryophyllene (17.22-26.27\%). The authors did not find a satisfactory antioxidant activity for the essential oil, with $\mathrm{EC}_{50}$ (concentration that caused $50 \%$ of the DPPH radical scavenging) values more than $236 \mathrm{mg} \cdot \mathrm{mL}^{-1}$ in the DPPH assay and a reduction of less than $11 \%$ in the $\beta$-carotene bleaching test [29]. There is a growing interest in the development of antioxidant substances, mainly from natural products [65].

\section{Material and Methods}

\subsection{Plant Material}

Leaves of L. thymoides were collected in the municipality of Abaetetuba (State of Pará, Amazon region, Brazil). The botanical identification (MG 213373) was performed in the Herbarium of the Museu Paraense Emílio Goeldi (Belém, State of Pará, Brazil).

\subsection{Thin-Layer Drying Kinetics of Lippia thymoides Leaves}

The drying kinetics were measured at 40,50 and $60^{\circ} \mathrm{C}$ using $12.03 \pm 0.05 \mathrm{~g}$ of fresh leaves. All assays were conducted in duplicate for $390 \mathrm{~min}$ using a convection oven (model SL-102, Solab, Piracicaba, São Paulo, Brazil) until reaching the equilibrium moisture content. The moisture content was determined according to the standard methods of analysis [66] at $105{ }^{\circ} \mathrm{C}$. After the experiments, the moisture ratio (XR) was calculated according to previous studies $[42,46,67]$.

Some mathematical models applied to describe the experimental drying kinetics of natural products were selected (Table 4): Lewis, Henderson \& Pabis, Page, Diffusion approach, Midilli, and Wang \& Singh, using a nonlinear regression procedure to estimate the parameters associated with each model.

Table 4. Mathematical models adjusted to the drying curves of Lippia thymoides leaves.

\begin{tabular}{ccc}
\hline Models & Equations & References \\
\hline Lewis & $\mathrm{XR}=\exp (-\mathrm{k} \times \mathrm{t})$ & {$[68]$} \\
Henderson \& Pabis & $\mathrm{XR}=\mathrm{a} \times \exp (-\mathrm{k} \times \mathrm{t})$ & {$[68,69]$} \\
Page & $\mathrm{XR}=\exp \left(-\mathrm{k} \times \mathrm{t}^{\mathrm{n}}\right)$ & {$[70]$} \\
Diffusion approach & $\mathrm{XR}=\mathrm{a} \times \exp (-\mathrm{k} \times \mathrm{t})+(1-\mathrm{a}) \times \exp (-\mathrm{k} \times \mathrm{b} \times \mathrm{t})$ & {$[38,71]$} \\
Midilli & $\mathrm{XR}=\mathrm{a} \times \exp \left(-\mathrm{k} \times \mathrm{t}^{\mathrm{n}}\right)+\mathrm{b} \times \mathrm{t}$ & {$[72]$} \\
Wang \& Singh & $\mathrm{XR}=1+\mathrm{a} \times \mathrm{t}+\mathrm{b} \times \mathrm{t}^{2}$ & {$[69,71]$} \\
\hline
\end{tabular}

Note: $k$ is the drying constant $\left(\min ^{-1}\right) ; \mathrm{a}, \mathrm{b}$, and $\mathrm{n}$ are the model coefficients. 


\subsection{Drying Conditions Versus Yield and Chemical Composition}

Samples of $90.11 \pm 0.06 \mathrm{~g}$ of fresh leaves were dried at $40{ }^{\circ} \mathrm{C}, 50{ }^{\circ} \mathrm{C}$, and $60{ }^{\circ} \mathrm{C}$ for $390 \mathrm{~min}$ in a convection oven. Then, the dried samples were subjected to hydrodistillation.

\subsubsection{Essential Oil Extraction}

Leaves of L. thymoides (fresh and dried) were subjected to hydrodistillation using a modified Clevenger glass extractor for $3 \mathrm{~h}$, as described by Nascimento et al. (2020) [73]. We utilized $30 \mathrm{~g}$ of plant material for each experiment. The yield (\%) of the essential oil was expressed as the percentage of oil in relation to the dry matter of the leaves.

\subsubsection{Analysis of Chemical Composition}

The chemical composition was analyzed with gas-phase chromatography coupled to mass spectrometry (GC/MS) using a Shimadzu QP 2010 Plus System (Shimadzu Corporation, Kyoto, Japan), equipped with silica capillary columns (DB-5MS, length of $30 \mathrm{~m}$, inner diameter of $0.25 \mathrm{~mm}$, and film thickness of $0.25 \mu \mathrm{m}$ ); carrier gas: helium, linear velocity: $36.5 \mathrm{~cm} \cdot \mathrm{s}^{-1}$; type of injection: splitless (solution of $2 \mu \mathrm{L}$ of oil in $500 \mu \mathrm{L}$ of hexane); injector temperature: $250{ }^{\circ} \mathrm{C}$, temperature range: $60^{\circ} \mathrm{C}$ to $250{ }^{\circ} \mathrm{C}$, gradient of $3^{\circ} \mathrm{C} \cdot \mathrm{min}^{-1}$; electron impact mass spectrometry: $70 \mathrm{eV}$; ion source temperature and connection parts: $220^{\circ} \mathrm{C}$. The quantification of each component was performed by peak-area normalization using a flame ionization detector (GC-FID, QP 2010 system, Shimadzu Corporation, Kyoto, Japan) under the same conditions as GC/MS, except for the carrier gas, which was hydrogen.

The components were identified based on the retention index (RI), which was calculated using the retention times of a homologous series of n-alkanes (C8-C40, Sigma-Aldrich, San Luis, Missouri, USA). The pattern of fragmentation observed in the spectra was compared with existing patterns of authentic samples in data system libraries and the literature [52].

\subsubsection{2,2-Diphenyl-1-picrylhydrazyl (DPPH) Free Radical Scavenging Assay}

The antioxidant activity of the essential oils was evaluated using the 2,2-diphenyl-1picrylhydrazyl (DPPH) radical scavenging method. A stock solution of DPPH (0.5 mM) was prepared in ethanol. The solution was diluted to approximately $60 \mu \mathrm{M}$, measuring an initial absorbance of $0.62 \pm 0.02$ at $517 \mathrm{~nm}$ at $22{ }^{\circ} \mathrm{C}$. The absorbance was measured at the start of the reaction, every $5 \mathrm{~min}$ during the first $30 \mathrm{~min}$, and then at $30 \mathrm{~min}$ intervals until a constant absorbance value (plateau of reaction, $2 \mathrm{~h}$ ). Each essential oil sample (50.0 $\mu \mathrm{L}$, $\left.20 \mathrm{mg} \cdot \mathrm{mL}^{-1}\right)$ was mixed with a Tween 20 solution $(0.5 \%, 50 \mu \mathrm{L}, w / w)$, and added to DPPH $(0.5 \mathrm{mM}, 1900 \mu \mathrm{L})$ in ethanol. The control sample was prepared in the same conditions, replacing the essential oil sample by ethanol. The standard curves were prepared using Trolox (6-hydroxy-2,5,7,8-tetramethylchroman-2-carboxylic acid) (Sigma-Aldrich, San Luis, Missouri, USA) at concentrations of $30 \mu \mathrm{g} \cdot \mathrm{mL}^{-1}, 60 \mu \mathrm{g} \cdot \mathrm{mL}^{-1}, 150 \mu \mathrm{g} \cdot \mathrm{mL}^{-1}, 200 \mu \mathrm{g} \cdot \mathrm{mL}^{-1}$, and $250 \mu \mathrm{g} \cdot \mathrm{mL}^{-1}$. The DPPH inhibition percentage and total antioxidant activity were expressed as milligrams of Trolox (mgTE. $\left.{ }^{-1}\right)$, as described by Choi et al. (2000) [74] and Figueiredo et al. (2019) [75].

\subsection{Statistical Analyses}

The most appropriate models to describe the drying kinetics curves were chosen based on the mean relative error (MRE, Equation (1)), standard error of estimate (SEE, Equation (2)), and coefficient of determination $\left(R^{2}\right)$. A MRE value of less than $10 \%$ was one of the criteria for selecting the best model [76]. Statistical analyses were conducted using Statistica ${ }^{\circledR} 13.1$ (TIBCO Software Inc., Palo Alto, CA, USA), and the Quasi-Newton method was applied. $\mathrm{N}$ represents the number of experiments, $\mathrm{df}$ the degrees of freedom, $\mathrm{XR}_{\exp }$ the experimental moisture ratio, and $\mathrm{XR}_{\text {pre }}$ the predicted moisture ratio.

$$
\mathrm{MRE}=\frac{100}{\mathrm{~N}} \sum_{\mathrm{i}=1}^{\mathrm{N}}\left|\frac{\mathrm{XR}_{\exp }-\mathrm{XR}_{\text {pre }}}{\mathrm{XR}_{\exp }}\right|
$$




$$
\mathrm{SEE}=\sqrt{\frac{\sum_{\mathrm{i}=1}^{\mathrm{N}}\left(\mathrm{XR}_{\mathrm{exp}}-\mathrm{XR}_{\mathrm{pre}}\right)^{2}}{\mathrm{df}}}
$$

The yield and antioxidant activity data were subjected to variance analysis (ANOVA) and their means were compared performing the Tukey test (at a significance level of $p$ $<0.05)$. Principal component analysis (PCA) was performed using a matrix correlation. In addition, the Euclidean distance and complete binding were used for the hierarchical cluster analysis (HCA) of the samples. The statistical analyses were conducted using Statistica ${ }^{\circledR} 13.1$ (TIBCO Software Inc., Palo Alto, CA, USA).

\section{Conclusions}

The study of drying kinetics provides data for the selection of the type of dryer as well as the best operating drying conditions. Midilli was the best model to describe the drying kinetics of L. thymoides leaves. In the present study, the drying conditions reached an appropriate moisture content for safe storage. The highest yields of essential oil were obtained from leaves that were dried at $40{ }^{\circ} \mathrm{C}$ and $50{ }^{\circ} \mathrm{C}$ after drying for $390 \mathrm{~min}$. The chemical composition showed a similar quantitative profile for all the drying conditions $\left(40,50\right.$ and $\left.60^{\circ} \mathrm{C}\right)$, but it differed from the chemical composition of the fresh material.

Thymol was the major compound identified in the essential oil obtained from fresh and dried leaves. The highest thymol content $(62.78 \pm 0.63 \%)$ and inhibition percentage of the DPPH radical $(89.97 \pm 0.31 \%$ ) were obtained from fresh leaves. Thus, $L$. thymoides can be a natural source of thymol, with levels greater than $50 \%$ of the composition of the essential oil.

Author Contributions: Conceptualization, L.D.d.N. and L.J.G.d.F.; Methodology, L.D.d.N., M.M.C. and P.L.B.F.; Software, S.G.S. and K.S.d.C.; Investigation, L.D.d.N., M.M.C. and P.L.B.F; Resources, E.H.d.A.A.; Writing—original draft preparation, L.D.d.N. and C.M.L.C.; Writing-review and editing, L.D.d.N. and K.S.d.C.; Supervision, C.M.L.C. and L.J.G.d.F.; Project administration, E.H.d.A.A. and L.J.G.d.F. All authors have read and agreed to the published version of the manuscript.

Funding: This research was funded by PROPESP (Federal University of Pará/Brazil) (Process 23073.007569/2021-81). We are grateful to them for their financial support of this research.

Institutional Review Board Statement: Not applicable.

Informed Consent Statement: Not applicable.

Data Availability Statement: Data is contained within the article.

Acknowledgments: The authors would like to thank the PROPESP (Federal University of Pará/Brazil) (Process 23073.007569/2021-81).

Conflicts of Interest: The authors declare no conflict of interest.

\section{References}

1. Mezza, G.N.; Borgarello, A.V.; Grosso, N.R.; Fernandez, H.; Pramparo, M.C.; Gayol, M.F. Antioxidant activity of rosemary essential oil fractions obtained by molecular distillation and their effect on oxidative stability of sunflower oil. Food Chem. 2018, 242, 9-15. [CrossRef] [PubMed]

2. Saeidi, K.; Moosavi, M.; Lorigooini, Z.; Maggi, F. Chemical characterization of the essential oil compositions and antioxidant activity from Iranian populations of Achillea wilhelmsii K. Koch. Ind. Crop. Prod. 2018, 112, 274-280. [CrossRef]

3. Zheljazkov, V.D.; Semerdjieva, I.B.; Dincheva, I.; Kacaniova, M.; Astatkie, T.; Radoukova, T.; Schlegel, V. Antimicrobial and antioxidant activity of Juniper galbuli essential oil constituents eluted at different times. Ind. Crop. Prod. 2017, 109, 529-537. [CrossRef]

4. Nascimento, L.D.; Moraes, A.A.B.d.; Costa, K.S.; Galúcio, J.M.P.; Taube, P.S.; Costa, C.M.L.; Cruz, J.N.; Andrade, E.H.d.A.; Faria, L.J.G. Bioactive Natural Compounds and Antioxidant Activity of Essential Oils from Spice Plants: New Findings and Potential Applications. Biomolecules 2020, 10, 988. [CrossRef] [PubMed]

5. Scalvenzi, L.; Grandini, A.; Spagnoletti, A.; Tacchini, M.; Neill, D.; Ballesteros, J.; Sacchetti, G.; Guerrini, A. Myrcia splendens (Sw.) DC. (syn. M. fallax (Rich.) DC.) (Myrtaceae) Essential Oil from Amazonian Ecuador: A Chemical Characterization and Bioactivity Profile. Molecules 2017, 22, 1163. [CrossRef] [PubMed]

6. Boukhatem, M.; Kameli, A.; Ferhat, M.; Saidi, F.; Tayebi, K. The food preservative potential of essential oils: Is lemongrass the answer? J. Consum. Prot. Food Saf. 2014, 9, 13-21. [CrossRef] 
7. Pandey, A.K.; Kumar, P.; Singh, P.; Tripathi, N.N.; Bajpai, V. Essential Oils: Sources of Antimicrobials and Food Preservatives. Front. Microbiol. 2017, 7, 1-14. [CrossRef] [PubMed]

8. Ghavam, M.; Manca, M.L.; Manconi, M.; Bacchetta, G. Chemical composition and antimicrobial activity of essential oils obtained from leaves and flowers of Salvia hydrangea DC. ex Benth. Sci. Rep. 2020, 10, 15647. [CrossRef]

9. Da Costa, K.S.; Galúcio, J.M.; Da Costa, C.H.S.; Santana, A.R.; Dos Santos Carvalho, V.; Do Nascimento, L.D.; Lima E Lima, A.H.; Neves Cruz, J.; Alves, C.N.; Lameira, J. Exploring the Potentiality of Natural Products from Essential Oils as Inhibitors of Odorant-Binding Proteins: A Structure- And Ligand-Based Virtual Screening Approach to Find Novel Mosquito Repellents. ACS Omega 2019. [CrossRef]

10. Liang, J.Y.; Guo, S.S.; Zhang, W.J.; Geng, Z.F.; Deng, Z.W.; Du, S.S.; Zhang, J. Fumigant and repellent activities of essential oil extracted from Artemisia dubia and its main compounds against two stored product pests. Nat. Prod. Res. 2018, 32, 1234-1238. [CrossRef]

11. Bertoli, A.; Conti, B.; Mazzoni, V.; Meini, L.; Pistelli, L. Volatile chemical composition and bioactivity of six essential oils against the stored food insect Sitophilus zeamais Motsch. (Coleoptera Dryophthoridae). Nat. Prod. Res. 2011, 1-9. [CrossRef]

12. Marchese, A.; Orhan, I.E.; Daglia, M.; Barbieri, R.; Di Lorenzo, A.; Nabavi, S.F.; Gortzi, O.; Izadi, M.; Nabavi, S.M. Antibacterial and antifungal activities of thymol: A brief review of the literature. Food Chem. 2016, 210, 402-414. [CrossRef]

13. Ranjbaran, A.; Kavoosi, G.; Mojallal-Tabatabaei, Z.; Ardestani, S.K. The antioxidant activity of Trachyspermum ammi essential oil and thymol in murine macrophages. Biocatal. Agric. Biotechnol. 2019, 20, 101220. [CrossRef]

14. Deng, L.L.; Taxipalati, M.; Que, F.; Zhang, H. Physical characterization and antioxidant activity of thymol solubilized Tween 80 micelles. Sci. Rep. 2016, 6, 1-8. [CrossRef] [PubMed]

15. Lima, E.L.F.; Macedo, W.R.; Silva, G.H. Effect of Thymol on Soybean Seeds Germination: Physiological and Biochemical Analysis. Brazilian Arch. Biol. Technol. 2019, 62. [CrossRef]

16. Braga, P.C.; Culici, M.; Alfieri, M.; Dal Sasso, M. Thymol inhibits Candida albicans biofilm formation and mature biofilm. Int. J. Antimicrob. Agents 2008, 31, 472-477. [CrossRef]

17. de Castro, R.D.; de Souza, T.M.P.A.; Bezerra, L.M.D.; Ferreira, G.L.S.; de Brito Costa, E.M.M.; Cavalcanti, A.L. Antifungal activity and mode of action of thymol and its synergism with nystatin against Candida species involved with infections in the oral cavity: An in vitro study. BMC Complement. Altern. Med. 2015, 15, 1-7. [CrossRef]

18. Numpaque, M.A.; Oviedo, L.A.; Gil, J.H.; García, C.M.; Durango, D.L. Thymol and carvacrol: Biotransformation and antifungal activity against the plant pathogenic fungi Colletotrichum acutatum and Botryodiplodia theobromae. Trop. Plant. Pathol. 2011, 36, 3-13. [CrossRef]

19. Boskovic, M.; Zdravkovic, N.; Ivanovic, J.; Janjic, J.; Djordjevic, J.; Starcevic, M.; Baltic, M.Z. Antimicrobial Activity of Thyme (Tymus vulgaris) and Oregano (Origanum vulgare) Essential Oils against Some Food-borne Microorganisms. Procedia Food Sci. 2015, 5, 18-21. [CrossRef]

20. Chauhan, A.K.; Kang, S.C. Thymol disrupts the membrane integrity of Salmonella ser. typhimurium invitro and recovers infected macrophages from oxidative stress in an ex vivo model. Res. Microbiol. 2014, 165, 559-565. [CrossRef]

21. Kowalczyk, A.; Przychodna, M.; Sopata, S.; Bodalska, A.; Fecka, I. Thymol and Thyme Essential Oil—New Insights into Selected Therapeutic Applications. Molecules 2020, 25, 4125. [CrossRef] [PubMed]

22. Ruberto, G.; Baratta, M.T. Antioxidant activity of selected essential oil components in two lipid model systems. Food Chem. 2000, 69, 167-174. [CrossRef]

23. Flora do Brasil. Lippia Thymoides. Available online: https://ala-bie.sibbr.gov.br/ala-bie/species/297714\#names (accessed on 5 March 2021).

24. The Plant List. Lippia Thymoides. Available online: http:/ / www.theplantlist.org/tpl1.1/search?q=Lippia+thymoides (accessed on 5 March 2021).

25. Plants of the World online. Lippia Thymoides. Available online: http://plantsoftheworldonline.org/taxon/urn:lsid:ipni.org: names:863852-1 (accessed on 5 March 2021).

26. Silva, F.S.; Menezes, P.M.N.; Sá, P.G.S.D.; Oliveira, A.L.D.S.; Souza, E.A.A.; Bamberg, V.M.; De Oliveira, H.R.; Oliveira, S.A.D.; Araújo, R.E.E.; Uetanabaro, A.P.T.; et al. Pharmacological basis for traditional use of the Lippia thymoides. Evid. Based Complement. Altern. Med. 2015, 1-10. [CrossRef]

27. Pinto, C.D.P.; Rodrigues, V.D.; Pinto, F.D.P.; Pinto, R.D.P.; Uetanabaro, A.P.T.; Pinheiro, C.S.R.; Gadea, S.F.M.; Silva, T.R.D.S.; Lucchese, A.M. Antimicrobial activity of Lippia species from the Brazilian semiarid region traditionally used as antiseptic and anti-infective agents. Evid. Based Complement. Altern. Med. 2013, 1-6. [CrossRef] [PubMed]

28. Silva, S.G.; de Oliveira, M.S.; Cruz, J.N.; da Costa, W.A.; da Silva, S.H.M.; Barreto Maia, A.A.; de Sousa, R.L.; Carvalho Junior, R.N.; Andrade, E.H.A. Supercritical CO2 extraction to obtain Lippia thymoides Mart. \& Schauer (Verbenaceae) essential oil rich in thymol and evaluation of its antimicrobial activity. J. Supercrit. Fluids 2021, 168, 105064. [CrossRef]

29. Silva, F.S.; Menezes, P.M.N.; Sá, P.G.S.D.; Oliveira, A.L.S.S.; Souza, E.A.A.; Da Silva, J.R.G.A.; Lima, J.T.D.; Uetanabaro, A.P.T.; Silva, T.R.D.S.; Peralta, E.D.; et al. Chemical composition and pharmacological properties of the essential oils obtained seasonally from Lippia thymoides. Pharm. Biol. 2016, 54, 25-34. [CrossRef]

30. Silva, S.G.; Da Costa, R.A.; De Oliveira, M.S.; Da Cruz, J.N.; Figueiredo, P.L.B.; Brasil, D.D.S.B.; Nascimento, L.D.; Chaves Neto, A.M.J.; De Carvalho, R.N.; De Aguiar Andrade, E.H. Chemical profile of lippia thymoides, evaluation of the acetylcholinesterase inhibitory activity of its essential oil, and molecular docking and molecular dynamics simulations. PLoS ONE 2019, 14, e0213393. [CrossRef] 
31. Silva, S.G.; Figueiredo, P.L.B.; Nascimento, L.D.; Costa, W.A.; Maia, J.G.S.; Andrade, E.H.A. Planting and seasonal and circadian evaluation of a thymol-type oil from Lippia thymoides Mart. \& Schauer. Chem. Cent. J. 2018, 12, 1-11. [CrossRef]

32. Prusinowska, R.; Śmigielski, K. Losses of essential oils and antioxidants during the drying of herbs and spices. A review. I Technol. Eng. Sci. Technol. 2015, 1. [CrossRef]

33. Gasparin, P.P.; Alves, N.C.C.; Christ, D.; Coelho, S.R.M. Quality of leaves and essential oil yield of peppermint (Mentha x piperita L.) submitted to the drying process in fixed-bed dryer. Rev. Bras. Plantas Med. 2014, 16, 337-344. [CrossRef]

34. Ko, H.C.; Jang, M.G.; Oh, J.M.; Park, J.Y.; Kim, J.E.; Kim, J.-W.; Baek, S.; Han, S.H.; Kim, S.-J. Changes in chemical composition and antioxidant activity of dried Citrus unshiu peel after roasting. LWT 2020, 131, 109612. [CrossRef]

35. Storck, R.C.; Deschamps, C. Yield and composition of essential oil of patchouli (Pogostemon cablin (Blanco) Benth.) after different drying periods in oven and at room temperature. Rev. Bras. Plantas Med. 2015, 17, 570-576. [CrossRef]

36. Pirbalouti, A.G.; Salehi, S.; Craker, L. Effect of drying methods on qualitative and quantitative properties of essential oil from the aerial parts of coriander. J. Appl. Res. Med. Aromat. Plants 2017, 4, 35-40. [CrossRef]

37. Mohammed, H.A.; Al-Omar, M.S.; Mohammed, S.A.A.; Aly, M.S.A.; Alsuqub, A.N.A.; Khan, R.A. Drying Induced Impact on Composition and Oil Quality of Rosemary Herb, Rosmarinus Officinalis Linn. Molecules 2020, 25, 2830. [CrossRef]

38. Perea-Flores, M.J.; Garibay-Febles, V.; Chanona-Pérez, J.J.; Calderón-Domínguez, G.; Méndez-Méndez, J.V.; Palacios-González, E.; Gutiérrez-López, G.F. Mathematical modelling of castor oil seeds (Ricinus communis) drying kinetics in fluidized bed at high temperatures. Ind. Crops Prod. 2012, 38, 64-71. [CrossRef]

39. Strumillo, C.; Kudra, T. Drying: Principles, Applications and Design; Gordon and Breach Science Publishers: Montreux, Switzerland, 1986; ISBN 0-677-21630-0.

40. Suvarnakuta, P.; Devahastin, S.; Soponronnarit, S.; Mujumdar, A.S. Drying kinetics and inversion temperature in a low-pressure superheated steam-drying system. Ind. Eng. Chem. Res. 2005, 44, 1934-1941. [CrossRef]

41. Pakowski, Z.; Mujumdar, A.S. Basic Process Calculations and Simulations in Drying. In Handbook of Industrial Drying; CRC Press: Boca Raton, FL, USA, 2006; p. 1312.

42. Lima-Corrêa, R.A.B.; Andrade, M.S.; da Silva, M.F.D.G.F.; Freire, J.T.; Ferreira, M.D.C. Thin-layer and vibrofluidized drying of basil leaves (Ocimum basilicum L.): Analysis of drying homogeneity and influence of drying conditions on the composition of essential oil and leaf colour. J. Appl. Res. Med. Aromat. Plants 2017, 7, 54-63. [CrossRef]

43. Reis, R.C.; Devilla, I.A.; Ascheri, D.P.R.; Servulo, A.C.O.; Souza, A.B.M. Kinetics of drying of basil leaves (Ocimum basilicum L.) in the infrared. Revosta Bras. Enhenharia Agrícola e Ambient. 2012, 16, 1346-1352. [CrossRef]

44. Essaqui, A.; Khoudali, S.; Es seddiki, S. Drying Effect on Yield and Chemical Composition of Essential Oils of Warionia saharae from Morocco. J. Essent. Oil-Bearing Plants 2016, 19, 1031-1036. [CrossRef]

45. Kucuk, H.; Kilic, A.; Midilli, A. Common Applications of Thin Layer Drying Curve Equations and Their Evaluation Criteria. In Progress in Exergy, Energy, and the Environment; Springer International Publishing: Cham, Switzerland, 2014; pp. 669-680.

46. Dorneles, L.N.S.; Goneli, A.L.D.; Cardoso, C.A.L.; Silva, C.B.; Hauth, M.R.; Oba, G.C.; Schoeninger, V. Effect of air temperature and velocity on drying kinetics and essential oil composition of Piper umbellatum L. leaves. Ind. Crops Prod. 2019, 142, 1-8. [CrossRef]

47. Alara, O.R.; Abdurahman, N.H.; Mudalip, S.K.A.; Olalere, O.A. Mathematical modeling of thin layer drying using open sun and shade of Vernonia amygdalina leaves. Agric. Nat. Resour. 2018, 52, 53-58. [CrossRef]

48. Rocha, R.P.; Melo, E.C.; Radünz, L.L. Influence of drying process on the quality of medicinal plants: A review. J. Med. Plant. Res. 2011, 5, 7076-7084. [CrossRef]

49. Ebadi, M.T.; Azizi, M.; Sefidkon, F.; Ahmadi, N. Influence of different drying methods on drying period, essential oil content and composition of Lippia citriodora Kunth. J. Appl. Res. Med. Aromat. Plants 2015, 2, 182-187. [CrossRef]

50. Mashkani, M.R.D.; Larijani, K.; Mehrafarin, A.; Badi, H.N. Changes in the essential oil content and composition of Thymus daenensis Celak. under different drying methods. Ind. Crops Prod. 2018, 112, 389-395. [CrossRef]

51. Alves, M.F.; Blank, A.F.; Arrigoni-Blank, M.F.; Fontes, S.S.; de Jesus, H.C.R.; Alves, P.B. Establishment of methodology for drying leaves and storage of essential oil of linalool chemotype Ocimum basilicum L. Biosci. J. 2015, 31, 1441-1449. [CrossRef]

52. Adams, R.P. Identification of Essential Oil components by Gas. Chromatography/ Mass Spectrometry, 4th ed.; Allured Publishing Corporation: Carol Stream, IL, USA, 2007; ISBN 97 8-1-932633-21-4.

53. Mondello, L. Flavors and Fragrances of Natural and Synthetic Compounds, Mass Spectral Database; FFNSC 2; John Wiley \& Sons Inc.: New York, NY, USA, 2011.

54. Shahhoseini, R.; Estaji, A.; Hosseini, N.; Ghorbanpour, M.; Omidbaigi, R. The Effect of Different Drying Methods on the Content and Chemical Composition of Essential Oil of Lemon verbena (Lippia citriodora). J. Essent. Oil-Bear. Plants 2013, 16, 474-481. [CrossRef]

55. Calín-Sánchez, Á.; Figiel, A.; Lech, K.; Szumny, A.; Carbonell-Barrachina, Á.A. Effects of Drying Methods on the Composition of Thyme (Thymus vulgaris L.) Essential Oil. Dry. Technol. 2013, 31, 224-235. [CrossRef]

56. Queiroz, G.A.; Silva, P.H.L.; Oliveira, R.A.d.; Sodré, G.A.; Costa, L.C.D.B. Drying temperature changes trichome integrity, chemical content and composition of the essential oil of pepper-rosmarin. Ciência Rural 2018, 48. [CrossRef]

57. Caesar, L.K.; Cech, N.B. Synergy and antagonism in natural product extracts: When $1+1$ does not equal 2. Nat. Prod. Rep. 2019, 36, 869-888. [CrossRef]

58. Bag, A.; Chattopadhyay, R.R. Evaluation of Synergistic Antibacterial and Antioxidant Efficacy of Essential Oils of Spices and Herbs in Combination. PLoS ONE 2015, 10, e0131321. [CrossRef] 
59. Huang, X.; Lao, Y.; Pan, Y.; Chen, Y.; Zhao, H.; Gong, L.; Xie, N.; Mo, C.-H. Synergistic Antimicrobial Effectiveness of Plant Essential Oil and Its Application in Seafood Preservation: A Review. Molecules 2021, 26, 307. [CrossRef]

60. Crespo, Y.A.; Bravo Sánchez, L.R.; Quintana, Y.G.; Cabrera, A.S.T.; Bermúdez del Sol, A.; Mayancha, D.M.G. Evaluation of the synergistic effects of antioxidant activity on mixtures of the essential oil from Apium graveolens L., Thymus vulgaris L. and Coriandrum sativum L. using simplex-lattice design. Heliyon 2019, 5, e01942. [CrossRef]

61. Kasrati, A.; Alaoui Jamali, C.; Fadli, M.; Bekkouche, K.; Hassani, L.; Wohlmuth, H.; Leach, D.; Abbad, A. Antioxidative activity and synergistic effect of Thymus saturejoides Coss. essential oils with cefixime against selected food-borne bacteria. Ind. Crops Prod. 2014, 61, 338-344. [CrossRef]

62. Ahmad, A.; van Vuuren, S.; Viljoen, A. Unravelling the Complex Antimicrobial Interactions of Essential Oils-The Case of Thymus vulgaris (Thyme). Molecules 2014, 19, 2896-2910. [CrossRef]

63. Rocha, P.; Rodilla, J.; Díez, D.; Elder, H.; Guala, M.; Silva, L.; Pombo, E. Synergistic Antibacterial Activity of the Essential Oil of Aguaribay (Schinus molle L.). Molecules 2012, 17, 12023-12036. [CrossRef] [PubMed]

64. Stanojević, L.; Stanojević, J.; Cvetković, D.; Ilić, D. Antioxidant activity of oregano essential oil (Origanum vulgare L.). Biol. Nyssana 2016, 7, 131-139. [CrossRef]

65. Oliveira, G.L.S. Determination in vitro of the antioxidant capacity of natural products by the DPPH•method: Review study. Rev. Bras. Plantas Med. 2015, 17, 36-44. [CrossRef]

66. Association of Official Analytical Chemists-AOAC. Official Methods of Analysis, 16th ed.; AOAC: Gaithersburg, MD, USA, 1997.

67. Do Nascimento, L.D.; Corumbá, L.G.; Rocha, S.C.S.; Taranto, O.P.; Costa, C.M.L.; De Faria, L.J.G. Mathematical Modeling of the Drying Curves of Foxtail Millet Seeds in Spouted Bed. Rev. Eng. Térmica 2015, 14, 18. [CrossRef]

68. Jittanit, W. Kinetics and Temperature Dependent Moisture Diffusivities of Pumpkin Seeds During Drying. Kasetsart J. Nat. Sci. 2011, 158, 147-158.

69. Sousa, K.A.D.; Resende, O.; Chaves, T.H.; Costa, L.M. The drying kinetics of forage turnips (Raphanus sativus L.). Rev. Ciência Agronômica 2011, 42, 883-892. [CrossRef]

70. Vega-Gálvez, A.; Miranda, M.; Díaz, L.P.; Lopez, L.; Rodriguez, K.; Di Scala, K. Effective moisture diffusivity determination and mathematical modelling of the drying curves of the olive-waste cake. Bioresour. Technol. 2010, 101, 7265-7270. [CrossRef] [PubMed]

71. De Faria, R.Q.; Teixeira, I.R.; Devilla, I.A.; Ascheri, D.P.R.; Resende, O. Drying kinetics of crambe seeds. Rev. Bras. Eng. Agrícola e Ambient. 2012, 16, 573-583. [CrossRef]

72. Midilli, A.; Kucuk, H.; Yapar, Z. A new model for single-layer drying. Dry. Technol. 2002, 20, 1503-1513. [CrossRef]

73. Nascimento, L.D.D.; Almeida, L.Q.; Sousa, E.M.P.d.; Costa, C.M.L.; Costa, K.S.D.; Andrade, E.H.D.A.; Faria, L.J.G.d. Microwaveassisted extraction: An alternative to extract Piper aduncum essential oil. Braz. J. Dev. 2020, 6, 40619-40638. [CrossRef]

74. Choi, H.-S.; Song, H.S.; Ukeda, H.; Sawamura, M. Radical-Scavenging Activities of Citrus Essential Oils and Their Components: Detection Using 1,1-Diphenyl-2-picrylhydrazyl. J. Agric. Food Chem. 2000, 48, 4156-4161. [CrossRef]

75. Figueiredo, P.L.B.; Pinto, L.C.; da Costa, J.S.; da Silva, A.R.C.; Mourão, R.H.V.; Montenegro, R.C.; da Silva, J.K.R.; Maia, J.G.S. Composition, antioxidant capacity and cytotoxic activity of Eugenia uniflora L. chemotype-oils from the Amazon. J. Ethnopharmacol. 2019, 232, 30-38. [CrossRef] [PubMed]

76. Mohapatra, D.; Rao, P.S. A thin layer drying model of parboiled wheat. J. Food Eng. 2005, 66, 513-518. [CrossRef] 